\title{
Testicular dysfunction in men with sickle cell disease
}

\author{
D.N. Osegbe and O.O. Akinyanju \\ College of Medicine, University of Lagos, Lagos Nigeria.
}

\begin{abstract}
Summary: In order to assess the role of the gonads and anterior pituitary gland in the production of poor quality semen of males with homozygous sickle cell disease (SCD) serum gonadotrophins, namely follicle stimulating hormone (FSH), luteinizing hormone (LH), prolactin and serum testosterone, were assayed radioimmunologically in 33 men with sickle cell disease and in 29 age-matched normal control subjects.

Our results show a significantly lower mean serum testosterone, a higher mean FSH and prolactin in SCD subjects than in normal controls. No single SCD subject had significantly low serum testosterone associated with low FSH, LH or prolactin.

The tendency for higher gonadotrophins associated with lower testosterone in subjects with SCD suggests that the hypothalamic/pituitary function in these patients is intact and that the primary fault leading to poor sperm production lies in the testes.
\end{abstract}

\section{Introduction}

Delayed sexual maturation has been observed in children with sickle cell disease (SCD). ${ }^{1}$ In 1981 , we evaluated the fertility potential of men with SCD, but who were in stable state, by examining their semen. The mean sperm density was $18 \times 10^{6} / \mathrm{ml} ; 18 \%$ were motile and $25 \%$ were well formed. In fact, no single semen sample of SCD patients met all the accepted minimum requirements for fertility. ${ }^{2}$

These observations suggest that both spermatogenesis and androgenesis are defective in SCD patients. In order to determine whether these impaired functions are due to an intrinsic (primary) defect of the testis or secondary to failure of the hypothalamus/ pituitary gland, the serum gonadotrophins (follicle stimulating hormone (FSH) and luteinizing hormone $(\mathrm{LH})$ prolactin and serum testosterone were assayed in these subjects. This paper reports our findings.

\section{Patients and methods}

Thirty three male patients with sickle cell disease (homozygous S and SC) whose ages ranged from 17 to 28 years with a mean of 20.2 (standard deviation 3.5 ) were studied. All the patients were in a clinically steady state and their haemoglobin $(\mathrm{Hb})$ types were determined by cellulose acetate electrophoresis at $\mathrm{pH}$ 8.4.

Correspondence: D.N. Osegbe, F.R.C.S., (Ed), Urology Unit, Department of Surgery, Lagos University Teaching Hospital, P.M.B. 12003, Lagos, Nigeria.

Accepted: 4 September 1986
Twenty nine males whose ages ranged from 18 to 27 years with a mean of 22.4 (s.d. 2.5) but without sickle cell disease served as controls (Table I).

Twenty millilitres of blood were collected from each subject into lithium heparin bottles between 1000 hours and 1200 hours and serum was separated immediately and stored at $-20^{\circ} \mathrm{C}$ until assayed.

Serum testosterone, FSH, $\mathrm{LH}$ and prolactin were measured by double antibody radioimmunoassay using reagents and standard sera from Radioassay Systems Laboratories, Carson, California. Samples from both groups were assayed in duplicate in one batch. The intra- and inter-assay coefficients of variation were $5.5-7.7 \%$ and $2.4-4.5 \%$ in the low and high range respectively. The results are recorded as mean and one standard deviation (s.d.) and statistical analyses were done by the Student's $t$ test method.

\section{Results}

The results are summarized in Table I. The study groups were well matched for age and population size.

Eight SCD patients (24.4\%) had raised serum FSH (range 22-70; mean 35.5, s.d. 16.9). In contrast none of the control subjects had a raised FSH. The mean level of the FSH in the SCD patients as a group was higher than that of the control group but the difference was not statistically significant $(P>0.1)$. Half of the patients $(12 \%)$ with raised FSH had significantly raised LH (mean $31 \mathrm{ng} / \mathrm{ml}$ ) and this was associated with low testosterone. The mean levels of $\mathrm{LH}$ in the 
Table I Serum gonadotrophins and testosterone in sickle cell disease

\begin{tabular}{|c|c|c|c|}
\hline & Controls & Sickle cell patients & $P$ \\
\hline Number of subjects $(n)$ & 29 & 33 & \\
\hline Age range in years & $18-27$ & $16-28$ & \\
\hline Mean age in years (s.d.) & $22.4(2.5)$ & $20.2(3.5)$ & n.s. \\
\hline \multicolumn{4}{|l|}{ Hb type } \\
\hline $\mathrm{AA}$ & 21 & & \\
\hline AS & 6 & & \\
\hline SS & & 31 & \\
\hline SC & & 2 & \\
\hline $\mathrm{AC}$ & 2 & & \\
\hline \multicolumn{4}{|l|}{$F S H(m I U / m l)$} \\
\hline Range & $2-21$ & $3-70$ & \\
\hline Mean \pm (s.d.) & $12.6(5)$ & $15.3(14.5)$ & n.s. \\
\hline Reference values & $4-20$ & $4-20$ & \\
\hline \multicolumn{4}{|l|}{$L H(n g / m l)$} \\
\hline Range & $6-25$ & $5-45$ & \\
\hline Mean \pm (s.d.) & $13.3(6)$ & $12.7(8.6)$ & n.s. \\
\hline Reference values & $4-20$ & $4-20$ & \\
\hline \multicolumn{4}{|l|}{ Prolactin $(n g / m l)$} \\
\hline Range & $5-26$ & $4-40$ & \\
\hline Mean \pm (s.d.) & $11.6(5.8)$ & $18(11)$ & $<0.05$ \\
\hline Reference values & $7-18$ & $7-18$ & \\
\hline \multicolumn{4}{|l|}{ Testosterone $(\mathrm{mg} / \mathrm{ml})$} \\
\hline Range & $2-10$ & $2-10$ & \\
\hline Mean \pm (s.d.) & $6.2(2.1)$ & $4.7(2.2)$ & $<0.01$ \\
\hline Reference values & $3-10$ & $3-10$ & \\
\hline
\end{tabular}

s.d. = standard deviation; n.s. = not significant.

two groups were however comparable $(P>0.05)$ (Table I).

The mean testosterone level for the patients as a group was significantly lower than that of the controls. Four SCD patients (12\%) had low serum testosterone levels of $2-3 \mathrm{ng} / \mathrm{ml}$.

The mean serum prolactin level was significantly higher in the patients than in the control group. About $40 \%$ of the SCD patients had serum prolactin levels in excess of the laboratory's upper limit of $20 \mathrm{ng} / \mathrm{ml}$, compared with $10 \%$ in the control subjects.

In all, no single patient had depressed values of FSH, LH and prolactin.

\section{Discussion}

The basic mechanism through which SCD produces lesions such as splenic infarcts, necrosis of the femoral head and papillary necrosis, is vasoocclusion of small blood vessels by the sickled red blood cells. If this also accounts for the depressed reproductive capacity reported by us, ${ }^{2}$ gonadal dysfunction may be the result of vasoocclusion of either hypothalamic-pituitary blood vessles which would result in low serum gonadotrophins (FSH, LH, prolactin) and consequently low testosterone (secondary hypogonadism) or vasoocclusion of the testicular vessels resulting ing target organ failure with low testosterone and high gonadotrophins (primary hypogonadism). It is also conceivable that vasoocclusion may affect both sys-윽 tems producing a complex of pituitary-testicular failure.

Our study shows that over $24 \%$ of adult SCD patients had high or severely elevated FSH. This means that these men have primary testicular failure.Furthermore, all 4 patients with low testosterone levels in this series had raised FSH and LH. Thisi suggests that pituitary function was intact but that the testes were unable to respond to stimulation in theseo patients. It is also of interest to note that serum $\mathrm{LH}^{-}$ was normal in $50 \%$ of the patients with high FSHO (seminiferous tubular failure). In other words, in half of the men who already showed hormonal evidence of seminiferous tubular failure, the Leydig cell function was normal. This suggests that the sperm producing cells were more susceptible to the damaging effect of SCD.

Olambinwonnu et al., ${ }^{3}$ in a study of SCD children, reported that gonadal function was depressed in thes first decade of life and reasoned that this was responsible for the delayed sexual maturation seen in these 
subjects. Surprisingly, they further reported that gonadal depression was transient and that function recovered after the age of 11 years. By implication therefore their report suggests that gonadal function would be normal in adult SCD.

Abassi et al. ${ }^{4}$ evaluated the pituitary-gonadal function of 14 adult SCD subjects and found gonadotrophin and androgen values consistent with primary testicular failure.

In contrast Dada \& Nduka $^{5}$ reported that all hormones, FSH, LH and testosterone, were subnormal in 19 SCD patients they studied and suggested gonadal dysfunction in SCD was of pituitary origin. Friedman et $a l^{6}{ }^{6}$ studied $8 \mathrm{SCD}$ patients and reported that the LH was elevated in 2 men.

Our results (the largest of all series so far reported) fail to support the transient nature of gonadal depression in SCD. In fact, the depression seems permanent and might well be responsible for the infertility in adults. Our results also conflict with the views of Dada $\& \mathrm{Nduka}^{5}$ that testicular failure was entirely the result of pituitary failure but agree with those of Abassi et $a l^{4}$ that testicular loss was extra-pituitary in origin. Our $24 \%$ incidence of primary gonadal failure agrees with $25 \%$ reported by Friedman and his colleagues. ${ }^{6}$

There is need for caution in interpreting the results of various studies. The age and clinical status of the patient are important factors to consider. Comparison of the hormonal status and response to stimulation of an SCD patient in the steady state of disease with another in crisis or just recovering from crisis may be erroneous. Landefeld $e t$ al. ${ }^{7}$ postulated a concept of partial hypothalamic dysfunction to explain hypogonadism in two 19 year old SCD patients who progressed from Tanner II to III by the third month of clomiphine therapy. These patients responded to GnRH and clomiphine stimulation with 2- to 4-fold increases of basal FSH, LH, and testosterone levels. The concept of partial hypothalamic defect was based on the extent of response to stimulation.

The patients however were not in a stable state. They were icteric, severely anaemic and had severe hepatic dysfunction, factors which may adversely affect basal testosterone levels and the responsiveness of the hypothalamus/pituitary to stimulation. Serjeant ${ }^{8}$ has rightly suggested that the inconsistent FSH and LH levels reported by various authors may be due to improper matching of subjects and their controls. Our subjects and controls were carefully

\section{References}

1. Ashcroft, M.T., Serjeant, G.R. \& Desai, P. Height, weights and skeletal age of Jamaican adolescents with sickle cell anaemia. Arch Dis Child, 1972, 47: 519-524.

2. Osegbe, D.N., Akinyanju, O.O.\& Amaku, E.O. Fertility matched for age and errors from this source were thus eliminated.

Hyperprolactinaemia occurred surprisingly in $39 \%$ of the SCD patients as against $10 \%$ in the controls. There does not appear to be any previous report of this hormone in SCD. The role of prolactin in spermatogenesis and steroidogenesis is at present unclear but hyperprolactinaemia is found in many infertile men. ${ }^{9}$ Whether the relationship is a cause or an effect or is a by-product of one or the other is also not known. Masala et al. ${ }^{10}$ strongly believe that hyperprolactinaemia can cause oligospermia but the effect on sperm quality of reduction to normal of raised prolactin in infertile males is disappointingly inconsistent. $^{10,11}$

Some of the common causes of hyperprolactinaemia, e.g. drugs, renal failure, primary hypothyroidism, were excluded in our patients. Anterior pituitary tumour, another cause of raised serum prolactin was not radiologically excluded in our patients at the time of this study. It was however considered unlikely to occur in such a high proportion in a small population of patients. In spite of this it is our intention to investigate them for pituitary tumour later.

Even though these patients were in a steady state, it is difficult to exclude emotional stress (a potent cause of elevated serum prolactin) in a chronic disorder which imposes a lot of frustration and anxiety.

Although the cause of hyperprolactinaemia in these patients is unclear, the elevated values of this hormone as well as FSH and LH suggest that hypothalamicpituitary function is intact in these subjects and therefore unlikely to be the cause of the reduced fertility we had earlier observed in these patients. Dynamic studies with LHRH testing and hCG stimulators in a large, well controlled group of subjects in steady state of disease are desirable in order to further evaluate both hypothalamic-pituitary as well as testicular functions in SCD subjects. Such a study is being organized by the authors.

\section{Acknowledgements}

This study was supported by the Research Grant of the College of Medicine, University of Lagos. Hormonal assays were done by Immunoassay Laboratories, Nigeria Limited, Lagos.

We also acknowledge the help of Mr R.A. Morakinyo who typed the manuscript. in males with sickle cell disease. Lancet, 1981, ii: 275-276.

3. Olambinwonnu, N.O., Penny, R. \& Frasier, S.I. Sexual maturation in subjects with sickle cell anaemia. Studies 
of serum gonadotrophin concentration, height, weight and skeletal age. $J$ Pediatr 1975, 87: 459-464.

4. Abbasi, A.A., Prasad, A.S., Ortega, J., Congo, E. \& Oberleas, D. Gonadal function abnormalities in sickle cell anaemia. Ann Int Med 1976, 75: 601-605.

5. Dada, O.A. \& Nduka, E.U. Endocrine function and haemoglobinopathies: relation between the sickle cell gene and circulating plasma levels of testosterone luteinizing hormone (LH) and follicle stimulating hormone in adult males. Clin Chim Acta 1980. 105: 269-273.

6. Friedman, G., Freeman, R., Bookchin, R., Boyar, R., Murthy, G., \& Hellman, L. Testicular function in sickle cell disease. Fertil Steril 1974, 25: 1018-1021.
7. Landefeld, C.S., Schambelan, M., Kaplan, S.L. \& Emburg, S.H. Clomiphene - responsive hypogonadism in sickle cell anaemia. Ann Int Med 1983, 99: 480-483.

8. Serjeant, G.R. In Sickle Cell Disease. 1st Ed. Oxford University Press, Oxford, 1985, p. 277.

9. Segal, S.P. \& Ben-David, M. Hyperprolactinaemic maleinfertility. Fertil Steril 1976, 27: 1425-1427.

10. Masala, A., Delitala, G., Alagna, S., Devilla, L., Rovasio, P.P. \& Lotti, G. Dynamic evaluation of prolactin secretion in patients with oligospermia: effects of treatment with metergoline. Fertil Steril 1979, 31: 63-67.

11. Pepperwell, R.G. Prolactin and reproduction. Fertil Steril 1981, 35: 267-274. 